\title{
Capacity Building for Dairy Farmers towards Commercialization of Green Corn Silage, Haylage and Urea Molasses Mineral Block
}

\author{
Nilo E. Padilla ${ }^{1, *}$, Joe Ann G. Payne ${ }^{1}$, Visitacion S. Simbulan ${ }^{1}$, Ralph John S. Lapastura ${ }^{2}$, \\ Errol John A. Cadeliña ${ }^{2}$ \\ ${ }^{1}$ Professor, College of Agriculture, University Director for R\&D, Isabela State University-Main Campus, 3309, Philippines \\ ${ }^{2}$ Project Staff, Isabela State University-Main Campus, 3309, Philippines
}

Received July 1, 2020; Revised August 11, 2020; Accepted September 11, 2020

\section{Cite This Paper in the following Citation Styles}

(a): [1] Nilo E. Padilla, Joe Ann G. Payne, Visitacion S. Simbulan, Ralph John S. Lapastura, Errol John A. Cadeliña , "Capacity Building for Dairy Farmers towards Commercialization of Green Corn Silage, Haylage and Urea Molasses Mineral Block," Universal Journal of Agricultural Research, Vol.8, No.6, pp. 233 - 240, 2020. DOI: 10.13189/ujar.2020.080604.

(b): Nilo E. Padilla, Joe Ann G. Payne, Visitacion S. Simbulan, Ralph John S. Lapastura, Errol John A. Cadeliña (2020). Capacity Building for Dairy Farmers towards Commercialization of Green Corn Silage, Haylage and Urea Molasses Mineral Block. Universal Journal of Agricultural Research, 8(6), 233- 240. DOI: 10.13189/ujar.2020.080604.

Copyright $\bigcirc 2020$ by authors, all rights reserved. Authors agree that this article remains permanently open access under the terms of the Creative Commons Attribution License 4.0 International License

\begin{abstract}
The study aimed to capacitate farmers as innovators in utilizing local feed resources for silage production, haylage, and Urea Molasses Mineral Block for commercialization. Commercialization among farmers hindered by: farmer's financing being supply-driven packages; limited programs designed to enhance farmer's entrepreneurship capabilities; scarce resources to invest on product's commercialization; and inadequate entrepreneurial competencies and exposure to business. After assessing their Personal Entrepreneurial Competence, training was undertaken through farmer based cooperative activities such as: assessment of farmer's personal entrepreneurial competencies; strategic analysis of cooperative competencies relative to environment; farmer's technical preparation; entrepreneurial competency enhancement; finance linkaging; and market linkaging/ market. The participatory operationalization components of farmers' capacity building resulted to: leaders' and members' active participation in planning and operationalization of trainings, mentoring, business plan preparations through resource sharing, decision-making and open discussions; increased support from government agencies; needs, resources, and capabilities of farmers' strengths and weaknesses became the hub of all capacity building activities; build-up of awareness on value of green corn as
\end{abstract}

silage raw material, provide alternative to decrease risks from natural calamities risks; advocated for more demand-driven financing programs of government; expansion of programs on shared facilities and machineries; opened market linkages for farmers; produced green corn silage; enhanced their capacities as entrepreneurs and leaders; integrators ushered their entry to silage commercialization as partners and raw material suppliers; and access to cooperative's financing requires prompt repayment and performance.

Keywords Capacity Building, Commercialization, Personal Entrepreneurial Competencies

\section{Introduction}

Personal Entrepreneurial Competencies (PEC) refer to the key characteristics that should be possessed by successful marketers in order to perform entrepreneurial functions effectively that entrepreneur must be geared up to take moves that go beyond his job requirements and to act faster and usually sooner than others and prepared to turn out to be a pacesetter inside the discipline of business. Entrepreneurial abilities are the traits of a man or woman to stumble on any new possibilities and stating up of an 
effective company in pursuit of the possibilities and define the necessary entrepreneurial capabilities. The most important responsibilities of an entrepreneur are innovation, income making, and popularity of opportunities, exchange and advent of ventures.

As indicated by Shelton et al. (2005), adoption of new technology is influenced by a number of factors: the technology must meet the needs of farmers; building relevant Cooperators enhances adoption; an understanding of the socio-economic context and skills of farmers and their farming systems is essential; participatory involvement of the rural communities enhances adoption.

Development projects of different types mainly aim to alleviate poverty and ameliorate the livelihoods of local people. One of the strategies commonly used is to focus on organizations and build from their existing capacities in order to improve their living standards or try to build new organizations to work in a common project. Social and human capitals are two key components of these organizations and they might be crucial to the success of the actions that they accomplish. Both can be considered as part of the social capacity of the local organization. This capacity can be enforced with development projects through capacity building. This term means much more than training activities as it includes not only human resource development but also organizational and institutional development (UNESCO, 2010).

Only minimal volumes (1\%) of dairy products are produced locally and this takes a lot of dollars while the poor are deprived of the nutrition they badly needed. In 2007, the government embarked on the improvement of the breeds of dairy livestock in the Philippines to reduce our dependency upon imported dairy products. Programs on milk feeding were institutionalized in June 8, 2005 by President Gloria M. Arroyo in her program called National Supplemental Feeding Program to expand the demand of local dairy products and reduce malnutrition among children in the country. In response to the dearth in Dairy products, the government imported livestock from Australia and New Zealand. The productivity of the dairy animals improved but the mortality of the imported stocks was discouraging among the small holders. Feeds became scarce as climate change brought unprecedented rain during the planting season and drought leaving brown and dry standing corn crops, some ready for harvesting in 3 to 4 weeks. Corn farming (1.5 has) as the main source of income of the farmers is too small to risk, hence the need to augment their income while ensuring minimal losses from early harvesting and processing their corn products into silage. It is in this context that the farmers must know how to maximize the utilization of their corn crops turning these into silage for sale and use of their livestock.

Enterprise development in the Dairy sector became the strategy undertaken in 2002 which led to the establishment of Dairy Zones where imported breeds of dairy animals were introduced as loans to the farmers. To ensure the effectiveness of the project, the farmers were capacitated on the production and management of the dairy animals and on the processing of their milk products.

\section{Conceptual Framework}

As shown in figure 1, the Dairy Farmers and officers of Malaya Development Cooperative and San Agustin Development Corporation were capacitated with a combination of farmer based cooperative activities such as: (1) assessment of the personal entrepreneurial competencies of the dairy farmers, (2) strategic analysis of cooperative competencies relative to the environment (3) technical preparation of the farmers (4) entrepreneurial competency enhancement and (5) finance/market linkaging. At the end of the study, the following were realized: (1) enhance farmer's skills/knowledge and (2) promote green corn silage/feed supplements, and (3) eventually commercialize the final product(s).

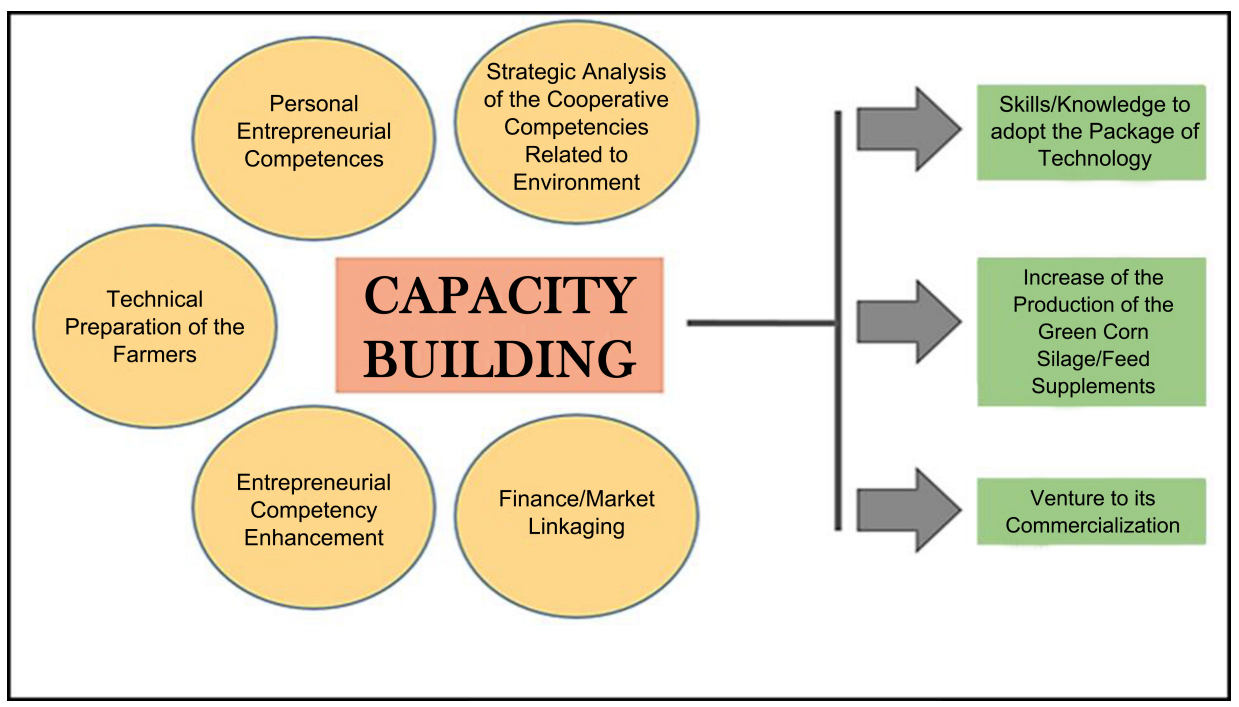

Figure 1. Conceptual Framework 
Table 1. Preparatory Activities Undertaken

\begin{tabular}{|l|l|l|}
\hline \multicolumn{1}{|c|}{ Activities } & \multicolumn{1}{|c|}{ Organization/Institutions } & \multicolumn{1}{c|}{ Persons Involved } \\
\hline Multi/Stakeholder Dialogues & LGU Mallig, LGU Quezon, LGU San Agustin & Mayor, Vice Mayor, MAO, Crop Managers \\
\hline Meetings with Officers & QuiDaCo, MDC and SADaCo & BOD and Officials of Cooperative \\
\hline Field Visits & $\begin{array}{l}\text { QuiDaCo, MDC SADaCo, First, } \\
\text { CAVADECO-NAMARCO, and Tanap }\end{array}$ & Manager, Officials, and Members \\
\hline Context Evaluation & $\begin{array}{l}\text { QuiDaCo, MDC SADaCo, First, } \\
\text { CAVADECO-NAMARCO, and Tanap }\end{array}$ & Manager, Officials, and Members \\
\hline $\begin{array}{l}\text { A SWOT Analysis Workshop } \\
\text { was Conducted }\end{array}$ & SADaCo and MDC Officials \& Members & Manager, Officials, and Members \\
\hline
\end{tabular}

\section{Methodology}

This study was conducted on August 24, 2027 to August 23, 2019 in the Municipalities of San Agustin and Mallig of the Province of Isabela.

\section{Data Collection and Respondents}

The result of the Personal Entrepreneurial Competencies (PEC) was used as the basis in the preparation of training design, mentoring and focus group discussion and evaluation of the capacity building/competencies undertaken by the farmer. Mentoring, benchmarking/field visits and evaluation with the farmers were also conducted to capacitate the farmers. (Please refer to Table 1).

The minds and acceptability of the project had to be internalized by the Board of Directors for support and active participation. Resources of the project, cooperatives, officers and members had to be committed towards the success of the project. Preparatory activities were undertaken before the entry of the project.

Selected dairy farmer-members with dairy animals of Malaya Development Cooperative (MDC) and San Agustin Dairy Cooperative (SADACO) were assessed on their Personal Entrepreneurial Competencies (PEC) using the PEC questionnaire used by the UP Institute for Small-Scale Industries (UP ISSI) and other organizations. This was conducted primarily to gather data on the level of entrepreneurial competencies of the farmers on the following; 1. Achievement cluster (opportunity-seeking and initiative, persistence, commitment, demand for efficiency and quality, taking calculated risks), 2.Planning cluster (goal setting, information seeking and systematic planning and monitoring) and 3. Power cluster (Persuasion and networking, Independence and self-confidence). The results of the PEC survey were used in the design of the upgrading process and sharing sessions. Using Likert Scale, the three group items were scored as 5- Always, 4- Usually, 3-Sometimes, 2-Rarely, and 1-Never. The results of the PEC were used in the design of upgrading process/capacity building, mentoring and focus group discussion.

Other sources of information were the evaluations undertaken by the farmers themselves during the upgrading process. These were collated and processed to find out the effectiveness of the capacity building done.
To validate the effectiveness of the upgrading process and mentoring undertaken, field visits and evaluation with the farmers were undertaken. Wherein Focus Group Discussions were extensively used, experiential learning with the participation of the farmers themselves, their products were also evaluated. Lessons were drawn immediately on the field with the results coming from the farmers.

\section{Results and Discussion}

\section{A series of multi-stakeholder dialogues were conducted}

This includes: (a) consultation meeting with the Local Government Unit (LGU) of Mallig, Isabela, (b) LGU San Agustin, Isabela, (c) Malaya Development Cooperative (MDC), and (d) Sinaoangan Sur Dairy Association of San Agustin Dairy Cooperative (SSDA of SADACO). These dialogues were initiated primarily to inform all stakeholders what the project is all about, what the project can offer duties and responsibilities of partner dairy cooperatives and their members, assistance needed from LGU of Mallig and LGU San Agustin (refer to Table 1). At the end of the dialogues, expectations of every stakeholder were elicited. Pledge of commitment of MDC and SSDA of SADACO has been ascertained. In all dialogues, the LGUs concerned provided the venue and some logistic support to include food for participants and accommodation for resource persons and training facilitators.

\section{Validation visits to project sites were conducted}

The research project team made ocular inspection of the cooperative's office, dairy project sites, forage areas, and other sites or properties of the partner cooperatives.

\section{Context evaluation was done}

Information and data collected (primary and secondary data) by the research team relevant to project operation and implementation were presented in an informal forum with LGU personnel particularly the Municipal Mayor, Municipal Agriculture Officer, and cooperative 
members/officers. Any incoherent or discrepancies were corrected.

\section{A SWOT analysis workshop was conducted}

Workshops participants include: a.) MDC Board of Directors, officers, and members, and b.) SSDA of SADACO Board of Directors, officers, and members. This workshop was conducted primarily to determine strengths (S) and weaknesses (W) of their cooperative which were internal to their organization. Opportunities $(\mathrm{O})$ and threats (T) which were external to their organization were likewise determined by the respective BODs, officers, and members of their respective cooperatives. A lecture was given to the workshop participants prior to SWOT analysis. The SWOT analysis was in relation to production, viability, probability and marketing of green corn silage (commercialization). In the said lectures, it was emphasized that "commercialization is a dynamic process involving several dimensions on technology, production, finance, markets, institutions, Infrastructure, facilities, political and social structure. Transforming the corn farmers from their way of life of farming to the commercialization of corn grains to silage requires the appropriate combination of resources within the different dimensions of commercialization. The project sought to elevate the corn farmers through their partnership with their cooperative venturing into commercialization of silage and its product.

STRENGTHS of partner cooperatives (MDC and SADACO) were as follows:

a). Both partner dairy cooperatives are located in Isabela, Region 02 (Cagayan Valley) where corn is abundant. As a matter of fact, in the DA-RFU 022017 Annual Report, Cagayan Valley Region ranked number one as corn producer of the country with Isabela Province as the highest corn producing province in the region. The agro-climatic conditions in both pilot sites (MDC and SADACO) are favorable for corn production. These conditions are favorable to the dairy farmers venturing in silage production and commercialization.

b). Both partner cooperatives and partner members owned at least three dairy cattle/buffalo per family head. These dairy cattle had been consistently fed with green corn for several years and these dairy farmers observed that with the appropriate quantity of quality feeds (silage) fed to their animals, there was a remarkable increase of milk production by their animals.

c). Presence of dairy processing facilities that served as "Common Service Facilities." Both cooperatives were given dairy milk processing facilities with accompanying infrastructure. SSDA of SADACO's milking barns located in several barangays served as temporary storage of silage during ensiling. MDC has a warehouse as temporary storage during ensiling. In both cooperatives, however, the area was not suited to large scale ensiling of green corn. The presence of these facilities serves as a driver for both cooperatives to ensure milk production at the members' level. These barns are temporarily used for silage storage by those who tried to produce silage due to delayed delivery of their dairy products.

d). Accessibility of dairy facilities (milking barn/parlor, forage area, processing facilities, office) was excellent. Presence of well-paved road network along the barangays. The PRDP has constructed concrete roads. The road network has a striking relationship among dairy projects and silage. History points out that commercial agriculture and the most dynamic farmers' organizations can be found along road networks. This is because the delivery of milk and other agricultural products becomes more efficient, saving the dairy farmer members' losses from spoilage.

e). In both partner dairy cooperative, the access to technologies needed in their business operation was not a problem since they have established linkages to the National Dairy Authority, Philippine Carabao Center and Isabela State University's technical assistance.

WEAKNESSES of partner cooperatives (MDC and SADACO) are the following:

a). Limited extension-cum research support to commercial silage. An interview with the farmer members of partner cooperatives pointed that silage is not one of the priorities of the government despite of the immediate needs of the dairy animals awarded to them. However, Silage commercialization has the potential as an integrating business for the farmers, as source of additional income of the corn farmers and as a mitigating measure of climate variability.

b). Limited access to traditional financing for commercialization. Financing for accompanying facilities has been newly integrated by the Department of Agriculture through the Agricultural Credit Policy Council (ACPC) loan packages. Commercial silage stakeholders face problems on traditional financing packages where the cooperatives are their conduits and uses group ownership. MDC did not qualify or do not have access to loan windows because of their cash strapped situation brought about by their unpaid production loans from the Land Bank of the Philippines (LBP). Modern equipment that will ensure the quality of silage was their immediate need if these farmers have to engage in silage commercialization. SSDA of SADACO, on the other hand, was qualified to avail/or have access to equipment/machinery assistance/loan through Agricultural Competitiveness Enhancement Fund (ACEF) or ACPC. However, the cooperative's BOD 
was adamant in pushing through the commercialization of silage. One of the 13 farmers associations that compose the SSDA of SADACO signified their interest and willingness to engage in commercializing silage but they need to use the name of SADACO, the umbrella cooperative, to have access to loan windows.

c). Inadequate entrepreneurial skills of BOD, officers and members of the partner cooperatives. The assessment of their entrepreneurial competencies would attest to this. They are weak in risk taking. Opportunity seeking, demand for quality, and persistence.

OPPORTUNITIES of partner cooperatives (MDC and SADACO) are the following:

a). Corn production in the Province of Isabela has a comparative advantage. Highly favorable to silage production, distribution and marketing to high demand areas like Batangas, Laguna, Cavite, Bulacan, Nueva Ecija, and Ilocos Region.

b). Availability of market for silage. In addition to Batangas, Laguna, Cavite, Bulacan and Nueva Ecija, commercial cattle farms in Cagayan Valley is in itself one the biggest market (20.71\% and Ilocos Region capturing $11.07 \%$. These provinces are very close to Metro Manila as a major market of milk and meat products. The Ilocos Region will continue to produce cattle as well, given the expanding market of meat and milk products. Other potential markets outside the country are Japan and Korea.

c). Success of the Research Project showcasing and promotion of silage production and commercialization can be replicated in other provinces/regions where corn production is abundant. Given the above considerations, the success of silage commercialization is worth replicating if given adequate support.

THREATS of partner cooperatives (MDC and SADACO) are the following:

a). Occurrence of calamities (strong typhoon, and unpredictable climate variability). Corn is one of the main products of small farmers in Isabela. Despite of the climate variability threats, the farmers still insist on producing corn because that was the only commodity they can produce with lower risk compared to other commodities.

b). Hesitance of some farmers to shift from corn grain production to silage production due to food security. Corn farming in an average area of 1.5 hectares is not worth risking given the access to loans from the middlemen and their need for food security of average of the family of 4 .

c). Stringent terms and conditions of financing windows. Lending Institutions like Land Bank and Rural Bank are very stringent in giving loans to Cooperative or individual farmers who have an outstanding loan balance from other lending institutions.

Table 2 shows the capability building activities undertaken by the project wherein hands-on training or experiential learning activities (do-it-your-own) for every POT, participatory visual evaluation of products during hands-on training exercises were undertaken, UMMB and haylage production outputs of the hands-on training were given to participants who fed these products to their dairy animals. Feedbacks were solicited from them on their observed effects, Demonstration feeding of green corn silage to lactating dairy cattle/buffalo of dairy farmer cooperators were also conducted, Printed copies of IEC materials of each POT were prepared and provided to members, Lakbay Aral to the different Dairy Cooperatives and private entrepreneurs for skills and product demonstration, symposium, lectures and write shop for capability building, Lakbay Aral, demonstration during Regional symposium, Mentored writeshop with coaching for capability building, Mentoring on how to have access to funding institution and Market linkaging with initial negotiations and market assessment was also undertaken.

Table 2. Participatory and Experiential Learning Activities Undertaken in the Project

\begin{tabular}{|ll|}
\hline \multicolumn{2}{|l|}{ Activities } \\
\hline a) & Hands-on training or experiential learning activities (do-it-your-own) for very package of technology (POT). \\
\hline b) & Participatory visual evaluation of products during hands-on training exercises. \\
\hline c) & $\begin{array}{l}\text { UMMB and haylage outputs of the hands-on training were given to participants and fed to their dairy animals. Feedbacks were solicited } \\
\text { from them on their observed effects. }\end{array}$ \\
\hline d) & Demonstration feeding of green corn silage to lactating dairy cattle/buffalo of dairy farmer cooperators. \\
\hline e) & Printed copies of IEC materials of each POT were prepared and provided to members. \\
\hline f) & $\begin{array}{l}\text { Lakbay Aral to the different Dairy Cooperatives and private entrepreneurs for skills and product demonstration, symposium, lectures } \\
\text { and write shop for capability building. }\end{array}$ \\
\hline g) & Lakbay Aral, demonstration during Regional symposium (done already). \\
\hline h) & Mentored writeshop with coaching for capability building. \\
\hline i) & Mentoring on how to have access to funding institution \\
\hline j) & Market linkaging with initial negotiations and market assessment. \\
\hline
\end{tabular}


Several Package of Technologies (POTs) for dairy cattle and buffalo were introduced to two partner cooperatives (Malaya Development Cooperative and San Agustin Dairy Cooperative). These are the POTs of: (1) production of green corn for silage, (2) green corn silage production processing, and storage, (3) production of haylage (Urea-Molasses Treated Rice Straw), and (4) UMMB (Urea Molasses Mineral Block).

These aforementioned technologies were first introduced in a series of capability building sessions called "seminar-workshops cum-experiential learning sessions". The main objects of these sessions were to enhance awareness, increase knowledge, and attract positive attitudes in the adoption of these technologies. In all these coaching-mentoring sessions, participants learned the tricks (the what, how, and the why) in adopting or applying the said POT. Products developed and packaged as refinement of the technologies introduced, received feedbacks, and were revised and applied their patent as "utility models". This study supports the idea of the study of Padilla, N., et. al, titled "Value Chain Analysis of Organic Range Chicken in Region 02. There is a need to increase competitiveness for the increase of shares in domestic and international markets (Padilla, N., et. al, 2020).

The POT's showcased in the two partner cooperatives were processed. One was done in Mallig, Isabela. The other one was done in Sinaoangan Sur, San Agustin, and Isabela. After ensiling the green corn, these were fed to test animals of MDC and SSDA of SADACO. Similarly, Green corn silage, Haylage and UMMB outputs during their upgrading process were given to test animals.

The effect of green corn silage fed to test animals has been observed and recorded by dairy-farmer cooperators. Towards the end of the second year of implementation, a survey was conducted to determine their effects and/or short-term impacts of feeding green corn silage, haylage, and UMMB, wherein $41.7 \%$ of the respondent experienced an increase of milk production ( $100 \%$ for dairy buffalo, $175 \%$ for dairy cattle) as their animals were fed the said POTs'. Above all, most of the respondent plan to increase their milk production and believed that additional income can be generated to their family and want their animals to continuously cross with the best performing breed of dairy animals to improve their animals' performance, In support of the study of Alam and Gosh (1994) that in order to increase productivity, the ideal animal breed must utilize for production.

The showcasing of the Package of technology by feeding to the dairy Cattle from MDC and Buffalo from SSDA of SADACO were done right after the capacity building seminar and observation of the animals were recorded over a short period of 10 weeks, after an adaptation period of two weeks. Field visits were carried out as the need arises to monitor the intake of silage feed and UMMB, milk production, and general health of the animals. The overall physical condition of the dairy animals was assessed using the scale of 1 to 5 ( 1 poor and 5 excellent) according to the procedure designed by Braun et al (1985).

At the end of the feeding trial, a survey and focus group discussion has been conducted among farmer cooperators to determine the perception of participating farmers regarding the feasibility of feeding silage, haylage, and UMMB as strategic supplemental feeds during dry season to lactating animals.

Initially, the target market of product(s) developed, packaged, and patented were the dairy farmer members of the partner cooperatives (MDC and SSDA of SADACO). This is with the end-in-view of a sustained increase in milk production of these cooperatives. Eventually, as adoption of green corn silage improves, market expands and radiates to other dairy cooperatives and private farms in Luzon, Visayas, and Mindanao and the neighboring countries.

Through the capacity building component of the project, the initial commercialization phase of green corn silage is set. Essentials for successful commercialization of green corn silage were in place except for haylage and UMMB. The POT for green corn production and POT for green corn silage were in place and patented. Lending windows for working capital requirements are there. The partner cooperatives have been provided information and working knowledge in the silage technology, business plan, trading, etc. The two partner cooperatives were willing to engage in the production and trading of green corn for silage, and/or green corn silage.

One stumbling block in the commercialization phase of silage as experienced in this project was the situation of the partner cooperatives. They were young, small and cash strapped to operate a business-like silage production and trading. They have to be weaned from their traditional farming activity and that is corn farming - planting corn, harvesting and selling corn grain. Silage making and sale of silage is new to them. This is the case of both partner cooperatives, the Malaya Development Cooperative (MDC) and SSDA of SADACO. Some members of the cooperatives were familiar in silage production but new in selling and marketing. They were cash strapped and had no money for working capital to procure machines and equipment (tractor, chopper, vacuum cleaner, among others). While there were loan windows available for working capital needed in the commercialization of silage, they have outstanding loans which disqualify them from having loan access. They have to pay/settle substantive amount of their outstanding loans. This is the case of MDC.

One scenario in the commercialization of silage is the emergence of "integrators"/collaborators from their members or private entrepreneurs. Integrators arise from the situation that silage can be produced and sold even if they do not have dairy cattle or buffalo. This was based on other component of the study wherein viability and probability of producing green corn silage was assessed, the collected financial viability studies revealed that the 
most profitable option for farmers, at $124.21 \%$ ROI, is to grow corn and sell the crop as a raw material for silage producers, specifically the partner cooperatives. The second most profitable options are for silage producers with their own livestock, garnering a 50.0\% and $46 \% 29 \%$ ROI. Nonetheless, the green corn-based value chain is an open opportunity for those who have the resources and are looking to improve productivity and diversification of income.

One member of MDC has been engaged in the production and sale of green corn silage. He was able to penetrate markets for silage to Cavite, Batangas, Nueva Ecija, Bulacan. He wanted to upgrade his operations but lending policies of LBP (i.e. ACEF) and Department of Agriculture (i.e. ACPC lending windows) are biased in favor of cooperatives, dairy associations and other practitioners. Individual borrowers are the least priority. The research team has been in the process of assisting him to be able to avail soft loans for his green corn business venture.

In SSDA of SADACO, the president of the SADACO signified his interest to venture into green corn silage production and marketing but encountered the same predicament as that of one of the dairy practitioners.

Commercialization of green corn for silage and green corn silage has shown bright and big market. However, there is a need to assist these emerging market integrators to enable them to adapt into the changing corn silage marketing paradigms and to be immersed into the dairy cattle feed value chain.

Table 3. Personal Entrepreneurial Competency of Officers and Members

\begin{tabular}{|c|c|c|c|c|}
\hline \multirow{2}{*}{$\begin{array}{c}\text { Personal } \\
\text { Entrepreneurial } \\
\text { Competency }\end{array}$} & \multicolumn{2}{|c|}{$\begin{array}{c}\text { Board of } \\
\text { Directors/Manager }\end{array}$} & \multicolumn{2}{c|}{ Members } \\
\cline { 2 - 5 } & $\begin{array}{c}\text { Mean } \\
\text { Scores }\end{array}$ & Interpretation & $\begin{array}{c}\text { Mean } \\
\text { Scores }\end{array}$ & $\begin{array}{c}\text { Interpret } \\
\text { ation }\end{array}$ \\
\hline Achievement & 17.21 & Moderate & .21 & Weak \\
\hline Planning & 16.11 & Moderate & 13.23 & Weak \\
\hline Power & 12.20 & Weak & 9.21 & Weak \\
\hline
\end{tabular}

The Personal Entrepreneurial Competencies (PEC) of the Partner Cooperatives were measured in the survey and validated in focus group discussions, coaching and mentoring. Changes in activities and approaches in the operationalization of the project activities were attuned and shaped according to the results of the PEC.

Table 3 shows that the PEC scores of the Board of Directors were better than the members. It has to be noted that the members of the BODs have moderate scores on Achievement where they scored as strong in opportunity seeking and initiative but scored moderately low on commitment, demand for efficiency and quality, and for taking calculated risks. Their trainings and exposure in the industry enhanced their capabilities to look for things that make their cooperative grow but can't risk the future of their cooperative since this is owned by the members and they feel they have to protect their name (integrity and honor).

On the other hand, the members were very weak in Achievement with moderate score in Commitment. According to the members, their opportunities in corn farming have been limited and selling dried corn does not require much knowledge. Selling their products is simple, since they sell their products to their private sources of loans.

The BODs have moderate score (16.11) on planning. They are strong (23.2) on goal setting, moderate on information seeking but very weak on systematic planning and monitoring. This could be explained by their exposure to internationally and nationally funded projects which trained and required them to produce their own plans in order to have access to funds and projects. On the other hand, majority of the members are weak when it comes to planning. Corn production is their way of life and access to opportunities has been limited. Their sources of information come from the Department of Agriculture (LGU, NDA and PCC) and their cooperative.

On the part of The Manager and the BODs were weak on power cluster specifically on persuasion and networking, independence but moderate on self-confidence. Exposure to the market, decision making and management of the cooperative would have honed their power cluster but the opposite showed otherwise. The Managers however had self-confidence strong (23.1). The results of the PEC were used in the design of upgrading process and mentoring, and focus group discussions. It was noted that these cannot be learned overnight.

\section{Conclusions and Recommendations}

- The emerging and existing farmer leaders actually tested the possibility of engaging in silage production.

- Engaging in a new business requires resources like financing, warehouse and equipment needed,

- The Officers and Managers of both cooperatives were exposed to various participatory and experiential learning methods (LGU, PRDP and DAR ARCESS Projects) before the start of the project,

- They participated actively in the actual demonstration methods of the production of silage and UMMB. Sinaoangan farmers even borrowed the shredder of the project,

- Internalizing the entrepreneurial competencies requires actual use of the competencies in their endeavors and this will take more years with entrepreneurial engagements. Two years of the project is inadequate. Learning the rudiments of entrepreneurship requires time and exposure to encouraging experiences and linkages, 
- Demand suited financing and market linkaging can be realized only through cooperative efforts with government assistance and one of them is the availability of loans for needed equipment and Credit Surety Fund Program (CSF) ownership of facilities like warehouses of the silage products and reaper shredder for immediate harvesting of quality green corn for quality packed silage. These are now offered by the Department of Agriculture but are not yet accessible during the duration of the project.

- Entrepreneurial competencies of small-scale farmers groups need to be enhanced if they are to be encouraged to participate in the processing, distribution, and marketing of silage;

- The emergence of "integrators" as stakeholders to participate in the commercialization of green corn silage is worth getting support both technical and financial assistance;

- $\quad$ Experiential learning seminars-workshops, coaching and mentoring session is recommended.

- Product transforms into a product life cycle which later on develops in the hands of small-scale farmers as the year goes by.

\section{REFERENCES}

[1] Ahmed, M.M., Ehui, S.K., \& Gebremedhin, B., 2003. Determinants of Adoption of Improved Forage Technologies in Crop-Livestock Mixed Systems: Evidence from the Highlands of Ethiopia. Tropical Grasslands. 37. 262-273.

[2] Alam, M.G.S. and Gosh, A., 1994. Plasma and Milk Progesterone Concentrations Early Pregnancy in Zebu Cows. Asian Australasian Journal of Animal Science 7: 131-136.

[3] Bran, R.K., Donovan, G.A., Trant, Q., Shearer, J.K., Blisse, L., Webb, D., Beede, D.K., \& Harris, B., 1985 Body Condition Scoring Dairy Cows as Herd Management Tool. Compendium Food Animal. University of Florida. pp. 6267. USA.

[4] H.M. Shelton, S. Franzel, M. Peters, 2005. Adoption of Tropical Legume Technology around the World: Analysis of Success. Tropical Grasslands. December 2005.

[5] Padilla, N., Payne, J.A., Simbulan, V., Guzman, C.D., Lapastura, R.J., Cadeliña, E.J., 2020. Value Chain Analysis of Organic Chicken in Region 02. Journal of Critical Reviews. ISSN-2394-5125. Vol. 7, Issue 11, 2020.

[6] UNESCO (2010) https://www.sciencedirect.com/science/ar ticle/pii/s1877042812013602\#bib0180

[7] Your Guide to Starting a Small Enterprise. Makati City, 2006. 